\title{
The never-ending story of the ideal valve
}

\author{
Can Yerebakan, MD, Lok Sinha, MD, and Manan Desai, MD
}

\footnotetext{
From the Division of Cardiovascular Surgery, Children's National Heart Institute, Children's National Health System, The George Washington University School of Medicine and Health Sciences, Washington, DC. Disclosures: Authors have nothing to disclose with regard to commercial support.

Received for publication July 24, 2018; accepted for publication July 24, 2018; available ahead of print Sept 12, 2018.

Address for reprints: Can Yerebakan, MD, Division of Cardiovascular Surgery, Children's National Heart Institute, Children's National Health System, The George Washington University School of Medicine, 111 Michigan Ave, NW, Washington, DC, 20010 (E-mail: cyerebakan@ childrensnational.org).

J Thorac Cardiovasc Surg 2019;157:726-7

$0022-5223 / \$ 36.00$

Copyright $(2018$ by The American Association for Thoracic Surgery

https://doi.org/10.1016/j.jtcvs.2018.07.076
}

Surgical options for the treatment of aortic valve disease in young patients remain suboptimal despite the time that has passed since the ideal valve substitute was characterized. ${ }^{1}$ The quest for a perfect valve substitute continues while we receive long-term data of different treatment strategies. The decision to use either a bioprosthetic or a mechanical heart valve substitute in patients whose valves are not amenable for a repair becomes critical in younger patient populations. Myriad factors influence surgical decision making in each case. Patient preferences have become equally important in this process and have found their well-deserved place in the guidelines. . $^{2,3}$

Milewski and colleagues ${ }^{4}$ provide a detailed description of comparative outcomes for mechanical versus biological valve substitutes for young adults undergoing aortic valve replacement surgery. The authors have to be congratulated for their nice study with long-term data covering 493 patient years. Their effort to have maximum echocardiographic follow-up and in-depth statistical analysis is commendable.

There are 2 important conclusions to be drawn from the study. First, when implanted in young adults, mechanical valves do not confer significantly higher freedom from reintervention. The indication of valve re-replacement might change but the risk of reoperation is real, high (not significantly lower than bioprosthetic valves), and incremental with time (actuarial freedom from reoperation was $69.4 \%$ vs $57.6 \%$ at 10 years, respectively). ${ }^{5}$ This subdues the advantage of durability of mechanical valves conferred by structural integrity because patients may ultimately undergo reoperations for other reasons. It would, however, be important to know the difference in terms of reintervention at longer-term follow-up. Bioprosthetic valves (stented and stentless) have been shown to have substantially lower freedom from reintervention beyond 15 years., The well-known risk of thromboembolic complications and bleeding that accompany mechanical valves means that they should not be considered as the sole choice for a valve replacement in young adults. degeneration.

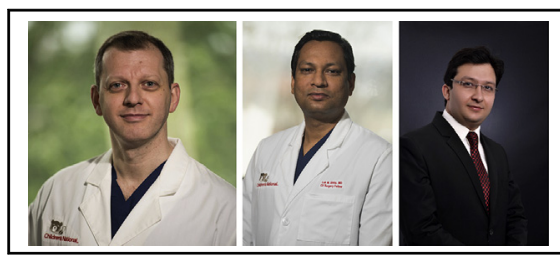

Can Yerebakan, MD, Lok Sinha, MD, and Manan Desai, MD

Central Message

The quest for a perfect valve substitute continues while we receive long-term data of different treatment strategies.

See Article page 714

Second, the risk of reoperation is almost doubled (increased by 1.9 times in this study) when valves with sizes at or below $21 \mathrm{~mm}$ are implanted, irrespective of the type of the valve. The results of the study have to be accepted with caution due to its retrospective, single-center nature, but prosthesis-patient mismatch has been a focus of intense research. ${ }^{7}$ If the risk of prosthesis-patient mismatch is high (predicted indexed effective orifice area $<0.75 \mathrm{~cm}^{2}$ / $\mathrm{m}^{2}$ ), consideration should be given to perform an elective root enlargement procedure in patients undergoing an aortic valve replacement. ${ }^{7}$ Nowadays, the implantation of a larger bioprosthetic valve is also tempting, given the amenability to future transcatheter valve-in-valve implantation for valve

The Ross operation still offers an excellent solution for young patients in specialized centers. Despite some reasonable criticism surrounding the risks of progressive autograft dilation and the need for homograft reoperations, long-term data of Ross operation outcomes in young adults are promising. 8,9 Thus, future studies need to clarify the available options for a valve replacement in younger populations by considering the excellent long-term outcomes after a Ross operation. Similarly, the Ozaki procedure with 3-leaflet replacement seems to have recently entered the quest. ${ }^{10}$ Long-term results in a population younger than in the published series for the Ozaki procedure will uncover the role of this innovative technique for valve replacement in this subset of patients. ${ }^{10}$ Moreover, tissue-engineered heart valves may offer a new pathway to an ideal valve substitute. ${ }^{11}$

The decision making in valvular heart surgery is so complex that it may offer a fertile field for employing artificial intelligence tools like cognitive computing and machine 
learning to design algorithms that aid humans in unbiased clinical decision making. ${ }^{12}$ But will such an approach help to meet our patients' needs in all cases?

\section{References}

1. Harken DE. Heart valves: ten commandments and still counting. Ann Thorac Surg. 1989;48:18-9.

2. Nishimura RA, Otto CM, Bonow RO, Carabello BA, Erwin JP, Guyton RA, et al. 2014 AHA/ACC guideline for the management of patients with valvular heart disease: a report of the American College of Cardiology/American Heart Association task force on practice guidelines. J Am Coll Cardiol. 2014;63:e57-185.

3. Falk V, Baumgartner H, Bax JJ, De Bonis M, Hamm C, Holm PJ, et al. 2017 ESC/ EACTS guidelines for the management of valvular heart disease. Eur J Cardiothorac Surg. 2017;52:616-64.

4. Milewski RK, Habertheuer A, Bavaria JE, Fuller S, Desai ND, Szeto WY, et al. Selection of prosthetic aortic valve and root replacement in young patients less than thirty years of age. J Thorac Cardiovasc Surg. 2019;157:714-25.

5. McClure RS, McGurk S, Cevasco M, Maloney A, Gosev I, Wiegerinck EM, et al. Late outcomes comparison of nonelderly patients with stented bioprosthetic and mechanical valves in the aortic position: a propensity-matched analysis. $J$ Thorac Cardiovasc Surg. 2014;148:1931-9.

6. Une D, Ruel M, David TE. Twenty-year durability of the aortic Hancock II bioprosthesis in young patients: is it durable enough? Eur J Cardiothorac Surg. 2014;46:825-30.

7. Moon MR, Pasque MK, Munfakh NA, Melby SJ, Lawton JS, Moazami N, et al Prosthesis-patient mismatch after aortic valve replacement: impact of age and body size on late survival. Ann Thorac Surg. 2006;81:481-8; discussion 489.

8. Yerebakan C. Do the best until we know better... Semin Thorac Cardiovasc Surg. 2017;29:502-3.

9. Sievers HH, Stierle U, Petersen M, Klotz S, Richardt D, Diwoky M, et al. Valve performance classification in 630 subcoronary Ross patients over 22 years. $J$ Thorac Cardiovasc Surg. 2018;156:79-86.

10. Reuthebuch O, Koechlin L, Schurr U, Grapow M, Fassl J, Eckstein FS. Aortic valve replacement using autologous pericardium: single centre experience with the Ozaki technique. Swiss Med Wkly. 2018;148:w14591.

11. Rieder E, Seebacher G, Kasimir M, Winter B, Dekan B, Wolner E, et al. Tissue engineering of heart valves. Circulation. 2005;111:2792-7.

12. Krittanawong C, Zhang H, Wang Z, Aydar M, Kitai T. Artificial intelligence in precision cardiovascular medicine. J Am Coll Cardiol. 2017;69: 2657-64. 